\title{
Pengaruh Olah Tanah Dan Jarak Tanam Terhadap Pertumbuhan Dan Hasil Bawang Tiwai (Eleutherine americana Merr.)
}

Sports Influence Soil And Plant Spacing on Growth and Results Onions Tiwai (Eleutherine americana Merr.)

\author{
Anita Rosita ${ }^{1}$, Rustam Baraq Noor ${ }^{2}$ dan Mahdalena ${ }^{2}$ \\ 1Alumni Program Studi Agroteknologi, Fakultas Pertanian, Universitas Widya Gama Mahakam \\ Jl. KH. Wahid Hasyim, Sempaja, Samarinda, Kalimantan Timur, Indonesia. \\ ${ }^{2}$ Tenaga Pendidik Program Studi Agroteknologi, Fakultas Pertanian, Universitas Widya Gama Mahakam \\ Jl. KH. Wahid Hasyim, Sempaja, Samarinda, Kalimantan Timur, Indonesia. \\ email : anitros@gmail.com, rusbnoor@gmail.com, mahdalen@yahoo.co.id
}

Diterima : 5 April 2012 Disetujui : 24 Agsutus 2012

\begin{abstract}
Effect of tillage and plant spacing on growth and yield of onion tiwai (Eleutherine americana Merr.). The purpose of this study was to evaluate the response of the growth and yield of onion tiwai to the treatment and processing of soil and plant spacing parameters diperlakukan.Penelitian was conducted for 3 months starting in December 2009 until March 2010, research carried out in Loa Janan Ulu Kutai regency. This research is a randomized block design Plots Divided (RAK split plot) with $2 \times 3$ factorial design, each treatment was repeated three times, the first factor of tillage (T) is t0: without tillage (control) t1: with processing soil, while the second factor is the spacing of $(\mathrm{J})$ is j1: $20 \times 25 \mathrm{~cm}, j 2: 25 \times 30 \mathrm{~cm}$ and j3: $30 \times 35 \mathrm{~cm}$. The results showed that treatment of tillage $(T)$ real berpengauh on plant height parameter ages of 30 and 60 days after planting, the number of chicks aged 60 and 90 days after planting, planting tuber number, tuber weight perpetak and tuber production tons per hectare, on plant height parameter of age 90 days after planting and the parameters of the number of seedlings 30 days after planting showed no significant effect. At the treatment plant spacing $(J)$ on all parameters showed no significant effect, ie plant height ages 30, 60 and 90 days after planting, the number of chicks aged 30, 60 and 90 days after planting, the number of tubers, tuber weight and tuber production tons perpetak per hectare. Interaction between tillage and planting distance (Tx $J)$ also showed no significant effect on all parameters: plant height is age 30,60 and 90 days after planting, the number of chicks aged 30, 60 and 90 days after planting, the number of bulbs, heavy perpetak bulbs and tubers production tons per hectare.
\end{abstract}

Keywords: Sports ground, plant spacing and onions tiwai

\section{PENDAHULUAN}

Indonesia terletak di daerah tropis yang memiliki berbagai tipe iklim, sehingga memungkinkan untuk mengembangkan berbagai jenis komoditas hortikultura, termasuk tanaman yang berpotensi obat seperti bawang Tiwai. Secara tradisional, kebanyakan masyarakat negara berkembang menggunakan tumbuhan disekitar mereka untuk mengatasi berbagai macam penyakit, Indonesia memiliki keanekaragaman hayati yang melimpah berupa tumbuh-tumbuhan, yang berupa tumbuhan obat, sehingga Indonesia menjadi negara terbesar kedua di dunia yang memiliki tumbuhan obat setelah Brazillia. Berbagai jenis tumbuhan telah dimanfaatkan oleh masyarakat sebagai obat

tradisional, salah satu diantaranya adalah bawang Tiwai/bawang Dayak yang dimanfaatkan oleh masyarakat pedalaman suku Dayak di pulau Kalimantan secara turun-temurun sebagai obat tumor dan kanker (Suroto dkk, 2006).

Kemajuan ilmu pengetahuan dan teknologi membuktikan bahwa bawang Tiwai banyak mengandung berbagai bahan kimia aktif, dintaranya senyawa golongan kimia alkaloid, steroid, triterpenoid, protein, saponin, karbohidrat dan senyawa-senyawa lainnya, yang telah dimanfaatkan oleh masyarakat modern sebagai obat sembelit, kanker, peluruh air seni, urus-urus, perangsang muntah dan untuk memperlancar air susu ibu. Ketersediaan bawang Tiwai yang tidak mencukupi, padahal tersedia potensi lahan yang cukup untuk mengembangkan tanaman tersebut. Mengingat jumlah penduduk Indonesia dari tahun ke tahun terus bertambah. Sehingga kebutuhan bahan tumbuhan berupa obat dan gizi masyarakat juga meningkat. Sementara budidaya tanaman obat belum mencukupi kebutuhan masyarakat (Laporan Pengembangan Wilayah, 1999). Potensi lahan yang luas memberikan peluang bagi upaya peningkatan produktifitas dan perbaikan teknologi atau budidaya masih dapat dilakukan. Namun menurut Leiwakabessy, 1988, terdapat beberapa kendala utama yaitu rendahnya produktivitas lahan ditandai dengan tingginya tingkat keasaman tanah, kekurangan unsur hara $\mathrm{P}, \mathrm{K}, \mathrm{Ca}$ dan $\mathrm{Mg}$, rendahnya Kapasitas Tukar Kation, kejenuhan basa dan kandungan bahan organic yang rendah, serta tingginya kadar $\mathrm{Al}$ dan $\mathrm{Mn}$ yang dapat meracuni tanaman dan tanah peka terhadap erosi.

Untuk memperoleh pertumbuhan dan hasil yang tinggi perlu dilakukan beberapa usaha, satu diantaranya adalah pengolahan tanah yang 
bermaksud mengubah keadaan tanah pertanian menggunakan alat pertanian hingga memperoleh susunan tanah sebaik-baiknya ditinjau dari persediaan air, udara dan derajat panas, yang dapat memungkinkan pertumbuhan dan perkembangan tanaman. Usaha lain untuk memperoleh pertumbuhan dan hasil yang tinggi adalah menghindarkan tanaman dari keadaan atau situasi berkompetisi dalam kehidupan tanaman, baik kompetisi dengan gulma (inter-species)

\section{BAHAN DAN METODE}

Penelitian dilaksanakan selama 3 bulan yaitu dimulai pada bulan Desember 2009 sampai dengan bulan Maret 2010, sedangkan lokasi penelitian ini dilaksanakan di Janan Ulu Kabupten Kutai Kartanegara. Bahan yang digunakan dalam penelitian ini adalah Bibit bawang tiwai, pupuk kandang, Furadan 3G dan Dhitane M-45. Alat yang digunakan adalah cangkul, parang atau sabit, meteran, ember atau gembor, handsprayer, timbangan, alat tulis menulis, dan alat-alat dokumentasi. Rancangan Acak Kelompok Petak Terbagi (RAK split plot) dengan pola faktorial 2 $\mathrm{X} 3$ yang masing-masing perlakuan diulang sebanyak $3 \mathrm{kali}$, faktor pertama pengolahan tanah (T) yaitu $t_{0}$ : tanpa pengolahan tanah (kontrol) $t_{1}$ : dengan pengolahan tanah, sedangkan faktor kedua maupun kompetisi dengan tanaman yang sama (intra-species). Kompetisi yang terjadi biasanya seperti kompetisi terutama dalam memperoleh hara, sinar matahari, dan air. Apabila kedua individu atau kelompok tanaman yang bersaing terus tumbuh, maka kuantitas faktor pertumbuhan yang diperoleh masing-masing pihak akan semakin jauh dibawah yang dapat diperoleh pada keadaan tanpa kompetisi (Pertumbuhan dan Produksi)

adalah jarak tanam (J) yaitu $\mathrm{j}_{1}: 20 \times 25 \mathrm{~cm}, \mathrm{j}_{2}: 25$ x $30 \mathrm{~cm}$ dan $\mathrm{j}_{3}: 30 \times 35 \mathrm{~cm}$. Pelaksanaan penelitian meliputi ; persiapan lahan, persiapan dan penanaman bibit, pemberian pupuk kandang, penyiraman, pengendalian gulma dan pengendalian hama dan penyakit. Parameter yang diamati ; tinggi tanaman, jumlah anakan, jumlah umbi per tanaman, berat umbi perpetak dan produksi umbi.Untuk melihat pengaruh tanaman terhadap perlakuan tersebut dilakukan analisis ragam, Jika hasil analisis ragam menunjukkan pengaruh yang nyata dari perlakuan yang diberikan maka analisis dilanjutkan dengan Uji Beda Nyata Terkecil (BNT) $5 \%$. Melalui uji BNT dapat diketahui perbedaan pengaruh antara masing-masing taraf dari faktor perlakuan.

\section{HASIL DAN PEMBAHASAN}

\section{Pengaruh Pengolahan Tanah}

Tabel 1. Rata-Rata Tinggi Tanaman pada Pengolahan Tanah

\begin{tabular}{cccc}
\hline \multirow{2}{*}{ Pengolahan Tanah } & \multicolumn{3}{c}{ Tinggi Tanaman $(\mathrm{cm})$ pada umur tanaman } \\
\cline { 2 - 4 } & $30 \mathrm{hst}$ & $60 \mathrm{hst}$ & $90 \mathrm{hst}$ \\
\hline $\mathrm{t}_{0}$ & $15,06^{\mathrm{a}}$ & $24,79^{\mathrm{a}}$ & 29,97 \\
$\mathrm{t}_{1}$ & $19,69^{\mathrm{b}}$ & $31,46^{\mathrm{b}}$ & 40,94 \\
\hline
\end{tabular}

Keterangan : Angka-angka yang diikuti huruf yang sama menunjukkan tidak berbeda nyata berdasarkan uji BNT pada taraf $\alpha=5 \%$

Tabel 2. Rata-Rata Jumlah Anakan pada Pengolahan Tanah

\begin{tabular}{cccc}
\hline \multirow{2}{*}{ Pengolahan Tanah } & \multicolumn{3}{c}{ Jumlah anakan (anak) pada umur tanaman } \\
\cline { 2 - 4 } & $30 \mathrm{hst}$ & $60 \mathrm{hst}$ & $90 \mathrm{hst}$ \\
\hline $\mathrm{t}_{0}$ & 1,08 & $1,41^{\mathrm{a}}$ & $3,44^{\mathrm{a}}$ \\
$\mathrm{t}_{1}$ & 0,93 & $2,28^{\mathrm{b}}$ & $9,17^{\mathrm{b}}$ \\
\hline
\end{tabular}

Keterangan : Angka-angka yang diikuti huruf yang sama menunjukkan tidak berbeda nyata berdasarkan uji BNT pada taraf $\alpha=5 \%$

Tabel 3. Rata-Rata Jumlah Umbi pada Pengolahan Tanah

\begin{tabular}{cc}
\hline Pengolahan Tanah & Jumlah Umbi (umbi) \\
\hline $\mathrm{t}_{0}$ & $2,62^{\mathrm{a}}$ \\
$\mathrm{t}_{1}$ & $4,34^{\mathrm{b}}$ \\
\hline
\end{tabular}

Keterangan : Angka - angka yang diikuti huruf yang sama menunjukkan tidak berbeda nyata berdasarkan uji BNT pada taraf $\alpha=5 \%$ 
Tabel 4. Rata-Rata Berat Umbi pada Pengolahan Tanah

\begin{tabular}{cc}
\hline Pengolahan Tanah & Berat Umbi $(\mathrm{kg})$ \\
\hline $\mathrm{t}_{0}$ & $0,45^{\mathrm{a}}$ \\
$\mathrm{t}_{1}$ & $1,17^{\mathrm{b}}$ \\
\hline
\end{tabular}

Keterangan : Angka - angka yang diikuti huruf yang sama menunjukkan tidak berbeda nyata berdasarkan uji BNT pada taraf $\alpha=5 \%$

Tabel 5. Rata-Rata Produksi pada Pengolahan Tanah

\begin{tabular}{cc}
\hline Pengolahan Tanah & Produksi (ton/ha) \\
\hline $\mathrm{t}_{0}$ & $3,02^{\mathrm{a}}$ \\
$\mathrm{t}_{1}$ & $7,15^{\mathrm{b}}$ \\
\hline
\end{tabular}

Keterangan : Angka - angka yang diikuti huruf yang sama menunjukkan tidak berbeda nyata berdasarkan uji BNT pada taraf $\alpha=5 \%$

Berdasarkan hasil sidik ragam perlakuan pengolahan tanah berpengaruh nyata terhadap parameter tinggi tanaman umur 30 dan 60 hari setelah tanam, jumlah anakan umur 30, 60 dn 90 hari setelah tanam, jumlah umbi perumpun, berat umbi perpetak dan produksi umbi ton/ha. Pengaruh nyata yang ditunjukkan masing-masing parameter penelitian pada perlakuan pengolahan tanah terhadap pertumbuhan tanaman bawang tiwai diduga karena fungsi pengolahan tanah dapat memperbaiki kondisi tanah. Perbaikan struktur dan penciptaan pori tanah yang bertujuan untuk meningkatkan massa air tanah bagi kebutuhan tanaman sehingga dapat terpenuhi secara baik, akibatnya suplai air bagi tanaman dapat terjamin. Dengan terpenuhinya kebutuhan air bagi pertumbuhan tanaman maka sudah dapat diduga bahwa, laju pertumbuhan dan perkembangan tanaman dapat dioptimalkan mengingat air merupakan bagian penting dari pemenuhan nutrisi tanaman sekaligus sebagai penyusun sel dalam pertumbuhan tanaman. Mengenai hubungan antara ketersediaan air dan efektivitas pemupukan tersebut Arsyad (2000) menjelaskan bahwa produksi optimum suatu tanaman dapat dicapai dengan pemupukan dan usaha-usaha perbaikan sifat-sifat fisik tanah. Akan tetapi pemupukan tidak akan berhasil dan menguntungkan sebelum perbaikan sifat fisik tanah seperti tersedianya air yang cukup dapat dipenuhi. Sebagaimana pendapat Utomo dan Ismail (1995) bahwa absorbsi air oleh tanaman selama pertumbuhan dan perkembangannya berubah sesuai dengan perkembangan tanaman. Pada awal pertumbuhan, karena permukaan transpirasi kecil maka absorbasi air oleh tanaman rendah. Absorbsi air tanaman akan meningkat dengan berkembangnya tanaman dan akan mencapai maksimum pada saat indeks luas daun maksimum. Bertambahnya ketersediaan air dalam tanah akibat pengolahan tanah guna memenuhi kebutuhan tanaman diharapkan mampu mendukung proses asimilasi sehingga pada akhirnya didapatkan laju pertumbuhan dan perkembangan tanaman yang lebih baik jika dibandingkan dengan tanaman yang berada pada lahan dengan ketersediaan air yang terbatas dan tergantung dari suplay air infiltrasi baik secara alami maupun ketersedian air karena penyiraman. Seperti yang dijelaskan oleh Fitter dan Hay (1998) bahwa laju pertumbuhan sel-sel tanaman dan efisiensi proses fisiologisnya mencapai tingkat tinggi bila sel-sel berada pada turgor maksimum yang tercipta karena ketersedian air yang cukup dari tanah. Sementara kemampuan tanah menyediakan air tergantung jumlah air yang mampu ditahan tanah sebagai sisa perbandingan antara presipitasi dan evapotranspirasi dan ditentukan pula oleh distribusi hujan dalam satu tahun. Bertambahnya ketersediaan air dalam tanah guna memenuhi kebutuhan tanaman diharapkan mampu mendukung proses asimilasi sehingga pada akhirnya didapatkan laju pertumbuhan dan perkembangan tanaman yang lebih baik jika dibandingkan dengan tanaman yang berada pada lahan dengan ketersediaan air yang terbatas akibat tidak diolahnya tanah sehingga tergantung dari suplay air infiltrasi secara alami saja. Seperti yang dijelaskan Harto (1993) bahwa, jenis tanah pasir (porositas tinggi) cendrung mempunyai laju infiltrasi tinggi, tetapi tanah liat (porositas rendah) sebaliknya cenderung mempunyai laju infiltrasi rendah, kepadatan media akibat dari tidak adanya pengolahan tanah juga mempengaruhi laju infiltrasi, makin padat maka makin kecil laju infiltrasinya.

Berpengaruhnya faktor pengolahan tanah (T) terhadap semua parameter pertumbuhan dan produksi kecuali parameter tinggi tanaman umur 90 hari setelah tanam, juga diduga karena tanah yang diolah mempunyai porositas tinggi sehingga perkembangan akar menjadi optimal akibatnya penyerapan hara dapat berlangsung optimal pula, juga didukung oleh ketersediaan hara pada tanah penelitian yang sangat mempengaruhi pola penyebaran sistem perakaran. Sesuai dengan pendapat Lakitan (2000) bahwa sistem perakaran tanaman lebih dikendalikan oleh sifat genetis dari tanaman yang bersangkutan, tetapi telah pula dibuktikan bahwa sistem perakaran tersebut dapat 
dipengaruhi oleh kondisi tanah atau media tumbuh tanaman. Faktor yang mempengaruhi pola penyebaran akar antara lain adalah penghalang mekanis, suhu tanah, aerase, ketersediaan air dan unsur hara. Berdasarkan hal tersebut pula, maka diduga bahwa pada tanah yang tanpa pengolahan $\left(\mathrm{t}_{0}\right)$ pertumbuhan dan produksi (hasil) tanaman menjadi tidak optimum dibandingkan dengan tanah yang dengan pengolahan $\left(\mathrm{t}_{1}\right)$, dimana perakaran (penyebaran akar) tidak berlangsung secara maksimal, sehingga penyerapan hara tersedia tidak dapat berlangsung optimal pula, sedangkan pada tanah dengan pengolahan $\left(\mathrm{t}_{1}\right)$, pada dasarnya pengolahan tanah bertujuan untuk menciptakan pori tanah, sehingga faktor-faktor pendukung dalam menciptakan kondisi kondusif bagi pertumbuhan dan perkembangan tanaman dapat terjamin ketersediaannya. Pendistribusian akar dapat berlangsung dengan baik yang didukung oleh porositas tanah yang baik, sehingga ketersedian $\mathrm{O}_{2}$ yang cukup,dan ketersediaan air sebagai media penghantar nutrisi-nutrisi keseluruh bagian tanaman, ditambahkan oleh Rismunandar (2003) bahwa usaha-usaha pengolahan tanah bertujuan antara lain menjamin tanah tetap subur dalam arti cukup mengandung zat-zat mineral, menjamin tanah cukup mengandung air, menjamin tanah tidak mudah

\section{Pengaruh Jarak Tanam}

Hasil sidik ragam menunjukkan bahwa perlakuan jarak tanam (J) tidak memberikan pengaruh nyata terhadap semua parameter yaitu Perlakuan jarak tanam pada semua parameter tidak menunjukkan pengaruh nyata, yaitu tinggi tanaman umur 30, 60 dan 90 hari setelah tanam , jumlah anakan umur 30,60 dan 90 hari setelah tanam, jumlah umbi, berat umbi perpetak dan produksi umbi ton per hektar. Tidak berpengaruhnya perlakuan jarak tanam ini diduga karena jarak tanam yang digunakan semuanya masih dapat memberikan ruang yang cukup bagi kebutuhan sinar matahari yang dibutuhkan oleh tanaman sehingga tidak ada kompetisi yang dapat saling merugikan antar species tanaman tersebut, tanaman dapat dengan mudah melakukan fotosintesis karena sinar matahari yang didapatkan cukup untuk kebutuhan tersebut. Sesuai dengan pendapat Fitter dan Hay (1998) bahwa pertumbuhan tergantung pada aktivitas sistem fotosintesis, maka hal ini tidak dapat dielakkan, tumbuhan mengalami tekanan seleksi yang intensif, baik pada kemampuan untuk menghasilkan bagian-bagian dimana fotosintesis terjadi maupun kemampuan agar supaya fotosintesis berjalan lebih efisien. Begitu pula dengan kebutuhan hara dengan jarak tanam yang diperlakukan yaitu $\mathrm{j}_{1}: 20 \times 25 \mathrm{~cm}, \mathrm{j}_{2}: 25 \times 30$ dan $\mathrm{j}_{3}: 30 \times 35 \mathrm{~cm}$ tidak berpotensi terjadi persaingan dalam memperoleh hara antar tanaman, sehingga kehilangan air. Ketersedian udara tanah juga merupakan faktor yang menjadi pendugaan, mengapa pengolahan tanah (T) berpengaruh nyata terhadap rata-rata parameter penelitian kecuali parameter tinggi tanaman umur 90 hari setelah tanam, dimana akar tanaman memerlukan udara untuk kegiatan respirasi yaitu penguraian karbohidrat menjadi energi yang diperlukan oleh tanaman untuk proses pertumbuhan dan perkembangan. Sesuai dengan pendapat Hanafiah (2005) bahwa oksigen diperlukan oleh sel-sel perakaran tanaman untuk melaksanakan resfirasi, yang melepaskan $\mathrm{CO}_{2}$ dan untuk oksidasi enzimatik oleh mircobia autotrifik (mampu menggunakan senyawa anorganik sebagai sumber energinya). Lebih lanjut dijelaskan oleh Hanafiah (2005) bahwa beberapa gas seperti $\mathrm{CO}_{2}$ dan $\mathrm{N}_{2}$ serta $\mathrm{NH}_{3}$ dan $\mathrm{H}_{2}$ dan gas-gas lainnya yang berasal dari proses dekomposisi bahan organik maupun dari sisa pestisida apabila berkadar terlalu tinggi dapat menjadi racun, baik bagi akar tanaman maupun bagi mikroba tanah. Adanya sirkulasi udara (aerasi) yang baik akan memungkinkan pertukaran gas-gas ini dengan $\mathrm{O}_{2}$ dari atmosfer, sehingga aktivitas microbial autotrofik yang berperan vital dalam penyediaan unsur-unsur hara menjadi terjamin dan toksinitas gas-gas tersebut ternetralisir.

tanaman dapat berkembang dengan baik tanpa ada tekanan akibat persaingan. hal tersebut sesuai dengan pendapat Sitompul dan Guritno (1995) bahwa kompetisi hara diantara bagian-bagian tanaman pada suatu tanaman yang sama akan ditentukan oleh bagian tanaman yang muda (pucuk), bagian tanaman yang muda pada fase vegetatif lebih banyak memerlukan hara, subtrat akan ditarik secara cepat untuk memenuhi kebutuhan fase tersebut, sehingga kompetisi intraspecies ini akan sangat merugikan bagian/organ tanaman yang lain, pada keadaan lapangan kompetisi biasanya mulai terjadi setelah tanaman mencapai tingkat pertumbuhan tertentu dan kemudian semakin keras dengan pertambahan ukuran tanaman dan umur, apabila bagian tanaman yang bersaing terus tumbuh, maka kualitas faktor pertumbuhan yang diperoleh masing-masing pihak akan semakin jauh di bawah yang dapat diperoleh bagian tanaman, dengan umur, ukuran dan proses yang terhambat akibat pemangkasan, maka proporsi kuantitas faktor pertumbuhan (makanan/subtrat) yang diperoleh oleh suatu bagian akan proporsional dengan kemampuan kompetitifnya.

Tidak jauh berbeda hal dengan kompetisi dalam pengambilan air, air merupakan faktor yang sangat penting dalam semua proses metabolisme tanaman, dimana air bermanfaat dalam menghantarkan hara (ion-ion) keseluruh tubuh tanaman, air dapat menjaga suhu tubuh tanaman, dan sangat berperan aktif dalam proses reaksi 
biokimia, sesuai dengan pendapat Fitter dan Hay (1984) bahwa air merupakan komponen utama tanaman hijau dan merupakan $70-90 \%$ berat tanaman tidak berkayu. Lebih lanjut Fitter dan Hay (1984) mengemukakan bahwa sifat tanaman yang menunjukkan keungulan persaingan, dimana persaingan cahaya dan ukuran organ yang berfotosintesis adalah hal yang kritis dan persaingan hanya akan berarti bagi suatu species

\section{Interaksi Pengaruh Pengolahan Tanah dan Jarak Tanam}

Berdasarkan hasil analisis ragam menunjukkan bahwa perlakuan pengolahan tanah dan jarak tanam $(\mathrm{T} \times \mathrm{J})$ tidak berpengaruh nyata terhadap semua parameter yaitu tinggi tanaman dan jumlah anakan umur 30, 60 dan 90 hari setelah tanam, jumlah umbi pertaman, berat umbi perpetak dan produksi umbi per hektar. Tidak berpengaruhnya interaksi pengolahan tanah dan jarak tanam (T x J) diduga disebabkan oleh pertumbuhan bawang tiwai yang masih leluasa dengan jumlah anakan yang ada sehingga jarak tanam yang diperlakukan yaitu $20 \times 25 \mathrm{~cm}, 25 \times 30 \mathrm{~cm}$ dan $30 \times 35 \mathrm{~cm}$ masih cukup memberikan ruang untuk pertumbuhan dan perkembangan khususnya pertumbuhan dan perkembangan anakan bawang tiwai, terlebih lagi pada perlakuan tanpa pengolahan tanah jumlah anakan lebih sedikit, hal ini sesuai dengan pendapat Sitompul dan Guritno (1995) bahwa kompetisi yaitu bagian tanaman dapat melindungi bagian tanaman yang lain atau bagian tanaman yang satu melindungi tanaman yang lain (kompetisi cahaya) atau kompetisi hara yang terjadi akibat perakaran tanaman yang saling bersaing dalam memperoleh hara, walaupun kompetisi untuk cahaya berbeda dengan kompetisi hara dan air yang sifatnya lebih aktif. Cahaya bukanlah suatu faktor yang terletak pada suatu sumber tanaman kemudian diambilnya, kompetisi

\section{KESIMPULAN}

1. Perlakuan pengolahan tanah rata-rata memberikan pengaruh nyata terhadap parameter tinggi tanaman umur 30 dan 60 hari setelah tanam, jumlah anakan umur 60 dan 90 hari setelah tanam, jumlah umbi, berat umbi per petak dan produksi ton per hektar, sedangkan parameter tinggi tanaman umur 90 hari setelah tanam dan jumlah anakan umur 30 hari setelah tanam menunjukkan tidak berpengaruh nyata. Produksi bawang tiwai tertinggi ditunjukkan oleh perlakuan $\mathrm{T}_{1}$ yaitu 7,15 ton/ha. subordinate untuk memberikan kompensasi bagi pertumbuhan dalam intensitas cahaya yang rendah, sebaliknya suplai air sampai pada tingkat tertentu bersifat difusi dan pengaruh posisi akar tidak menjadi penting, dalam hal ini kuantitas relatif dari sistem perakaranlah yang terpenting, akar menjadi penentu kecepatan relatif pengambilan air.

cahaya bersifat pasif dimana tanaman tidak benyak melakukan gaya untuk mendapatkan cahaya yang banyak. Faktor pengolahan tanah yang memberikan keleluasaan bagi akar tanaman untuk berkembang dalam memperoleh hara juga tidak membentuk persaingan (kompetisi) antar species tanaman sehingga dapat disimpulkan tidak ada keterkaitan diantara keduanya dalam hal mendorong pertumbuhan dan perkembangan tanaman, sehingga dapat dikatakan pula bahwa masing-masing faktor bertindak atau berdiri sendiri-sendiri, hal tersebut sesuai dengan pendapat Steel dan Torrie (1989), bahwa apabila interaksi antara faktor yang satu dengan faktor lainnya tidak berpengaruh, maka dapat dikatakan bahwa faktor-faktor tersebut bertindak bebas atau tidak tergantung satu sama lainnya. Ditambahkan oleh Hanafiah (2000) bahwa faktor pertama (pengolahan tanah) dan faktor kedua (jarak tanam) jika keduanya berpengaruh sangat nyata dan berpengaruh nyata, sedangkan interaksinya tidak berpengaruh nyata maka faktor pertama dan kedua diterapkan secara terpisah saja, karena fungsi masing-masing faktor bersifat antagonis (saling menekan pengaruh masing-masing), yang akan dapat merugikan jika diterapkan bersama-sama. Jika faktor pertama berpengaruh nyata dan faktor kedua tidak berpengaruh nyata, maka penerapannya adalah faktor pertama saja atau sebaliknya.

2. Perlakuan jarak tanam pada semua parameter tidak menunjukkan pengaruh nyata, yaitu tinggi tanaman umur 30, 60 dan 90 hari setelah tanam, jumlah anakan umur 30, 60 dan 90 hari setelah tanam, jumlah umbi, berat umbi perpetak dan produksi umbi ton per hektar.

3. Interaksi antara pengolahan tanah dan jarak tanam ( $\mathrm{T} \quad \mathrm{x}$ J) juga menunjukkan tidak berpengaruh nyata pada semua parameter yaitu tinggi tanaman umur 30, 60 dan 90 hari setelah tanam, jumlah anakan umur 30, 60 dan 90 hari setelah tanam, jumlah umbi, berat umbi perpetak dan produksi umbi ton per hektar. 


\section{DAFTAR PUSTAKA}

Arsyad, S. 2000, Konservasi Tanah dan Air. Institut Pertanian Bogor (IPB) Press. Bogor.

Fitter. A.H dan Hay. R.K.M, 1998, Fisiologi Lingkungan Tanaman, (Diterjemahkan Oleh Sri Andani dan Purbayanti), Gadjah Mada University Press, Yokyakarta.

Hanafiah AK, 2005, Dasar-Dasar Ilmu Tanah, Raja Grafindo Persada, Jakarta.

Harto. SBR, 1993, Analisis Hidrologi, Gramedia Pustaka Utama, Jakarta.

Lakitan, 2000, Fisiologi Tanaman. Raja Grafindo Persada, Jakarta.

Laporan Pengambangan Wilayah, 1999, Analisis Data Pokok Untuk Pembangunan Wilayah Provinsi KalTim, Badan Pengkajian Teknologi Pertanian (BPTP) Prop. Dati Kal-Tim, Samarinda.

Leiwakabessy, F.M. 1988. Kesuburan Tanah. Jurusan Ilmu Tanah Fakultas Pertanian Bogor. Institut Pertanian Bogor.

Rismunandar, 2003, Tanah dan Seluk Beluknya Bagi Pertanian, Sinar Baru Algesindo, Bandung.

Sitompul SM dan Guritno B, 1995, Analisis Pertumbuhan Tanaman, Gadjah Mada University Press, Fakultas Pertanian Universitas Brawijaya, Malang.

Steel, RGD and JH Torrie, 1989, Prosedur Statistik Untuk Penelitian Pertanian (Terjemahan : Endang Syamsudin dan Justika S. Baharsyah) Edisi Kedua Universitas Indonesia, Press, Jakarta.

Utomo W. H dan T. Ismail, 1995, Hubungan Tanah, Air dan Tanaman. IKIP Semarang Press. Semarang. 